\title{
FITOACUMULATION OF Mn AND Fe ON NYPA FRUTICANS IN TALLO RIVER, MAKASSAR
}

\author{
Zulfikar $^{1 *}$, Nursiah La Nafie ${ }^{1}$ dan Syarifuddin Liong ${ }^{1}$ \\ ${ }^{1}$ Department of Chemistry, Faculty of Mathematics and Natural Sciences, Hasanuddin University, Perintis \\ Kemerdekaan Street KM 10, Tamalanrea Makasssar, Indonesia 90245 \\ *Corresponding author: zulfikaridris94@ gmail.com
}

\begin{abstract}
Abstrak. Penelitian tentang fitoakumulasi Mn dan Fe dalam tumbuhan nipah (Nypa fruticans) dilakukan dengan tujuan untuk mengetahui potensi fitoakumulasi tumbuhan Nypa fruticans di Sungai Tallo. Sampel diambil pada air, sedimen, akar, pelepah, dan daun di lima titik sampling yang mewakili area tercemar oleh aktivitas kawasan industri dan pemukiman masyarakat. Sampel air didestruksi dengan $\mathrm{HNO} 3$ pekat, sedangkan sampel sedimen didestruksi kering dengan $\mathrm{Na} 2 \mathrm{CO} 3$ dan NaHCO3, kemudian dilarutkan dengan akuaregia dan sampel bagian tumbuhan didestruksi basah dengan HNO3 6 M dan $\mathrm{H} 2 \mathrm{O} 2$ pekat dan dianalisis menggunakan ICP EOS Shimadzu 9000. Hasil analisis menunjukkan bahwa Nypa fruticans mampu mengakumulasi Mn dan Fe, selain itu kemampuan akumulasinya menunjukkan bahwa secara alami tumbuhan ini hiperakumulator terhadap Fe namun tidak hiperakumulator terhadap Mn. Berdasarkan hasil perhitungan BCF dan TF, maka mekanisme fitoakumulasi Nypa fruticans terhadap Mn dan Fe adalah fitostabilisasi.
\end{abstract}

Kata kunci: $\mathrm{Mn}, \mathrm{Fe}$, nipah, fitoakumulasi, hiperakumulator.

Abstract. The phytoaccumulation of $\mathrm{Mn}$ and Fe in nipah palm (Nypa fruticans) has objective to find out the phytoaccumulation potential of Nypa fruticans in Tallo river. Samples were taken in water, sediments, roots, midribs and leaves at five sampling spots representing polluted areas by activities of industrial estates and community settlements. Water was destructed by concentrated HNO3, meanwhile sediments were destructed by dry destruction with aquaregia and plant tissues were destructed by wet destruction with $\mathrm{HNO} 36 \mathrm{M}$ and concentrated $\mathrm{H} 2 \mathrm{O} 2$, then all the samples were carried on analysis using ICP EOS Shimadzu 9000. The result of analysis has shown that Nypa fruticans was able to accumulate $\mathrm{Mn}$ and $\mathrm{Fe}$, moreover the accumulation potential indicated Nypa fruticans able to be natural hyperaccumulator for Fe, otherwise to $\mathrm{Mn}$. According to $\mathrm{BCF}$ and TF result were shown the mechanism of phytoaccumulation in Nypa fruticans for $\mathrm{Mn}$ and $\mathrm{Fe}$ as phytostabilization.

Keywords: Mn, Fe, Nypa fruticans, phytoaccumulation, hyperaccumulator. 


\section{INTRODUCTION}

The industry is one of economic development that increases regularly and very promising a better future for the community economy (Widowati, et al, 2008). The development of the industrial sector provides a positive impact in the form of the expansion of employment and increased incomes, while disruptive is the high rate of change of land use which is not in accordance with the rules of ecology, urbanization is less controlled, high population growth, as well as the pollution of waters due to the disposal of wastewater that goes beyond the threshold (Setiawan, 2014). Various human activities such as the remaining results of domestic waste and agriculture provide a negative impact on the area of the estuary and coast (Kariada and Irsadi, 2014).

The management of waste containing heavy metals, especially liquid waste conventionally start perceived ineffective and difficult. Therefore needed some alternative waste treatment liquid and effective use of environmentally friendly technology. One way of processing is to use aquatic plants that have the ability to absorb and accumulate heavy metals (Juhaeti, et al., 2004). The diversity of endemic plant species that exist in Indonesia is very high. Types of flora that belong to Indonesia very much has the potential to reduce pollution from contaminated environments in this aquatic plants, one of which is the mangrove plant or the like. Indonesia as one of the countries with extensive mangrove forest is the world's largest or the like (Juhaeti et al., 2004).

Tallo River is located in the northern side of the Makassar city experienced high pressure due to the existence of settlements, industrial areas of Makassar (KIMA), PLTU, farming and agriculture (Setiawan, 2014). Existing industries around the river causing Tallo River polluted by industrial wastes. Heavy metal waste is one of the polluters in the river Tallo.

Station 1 is located on the East side of the Perintis Kemerdekaan street near the area of bridges between Perintis Kemerdekaan street and Dr. Leimena street. Station 2 is located in the vicinity of the bridge after Perintis Kemerdekaan Road and PLTU Makassar toward the Kera-Kera dock. Station 3 is located around the Delta Lakkang towards Sinri Jala. Station 4 is located in Pampang River. Station 5 is located at the $\mathrm{t}$ junction Sinri Jala leading to the coastal town of Makassar.

The position of the specified stations is representatively determined based on the situation and conditions in Tallo River, which can represent the points of the existing pollution. Sampling was done on a five-point, namely:

1. The station 1 is located at the coordinates S 5 $8^{\prime}$ 37.904" and E $119^{\circ} 28^{\prime} 45.737^{\prime \prime}$

2. Station 2 is located at the coordinates $S$ $5^{\circ} 8^{\prime} 40.366^{\prime \prime}$ and E 119²8'22.496"

3. Station 3 is located at the coordinates $S$ $5^{\circ} 7 ' 20.723$ "and E 119²7'39.349" 
4. Station 4 is located at the coordinates $\mathrm{S}$ $5^{\circ} 8^{\prime} 22.902$ "and E $119^{\circ} 26^{\prime} 42.684^{\prime \prime}$

5. Station 5 is located at the coordinates $\mathrm{S}$ 56'53.650 "and E 119²6'59.092"

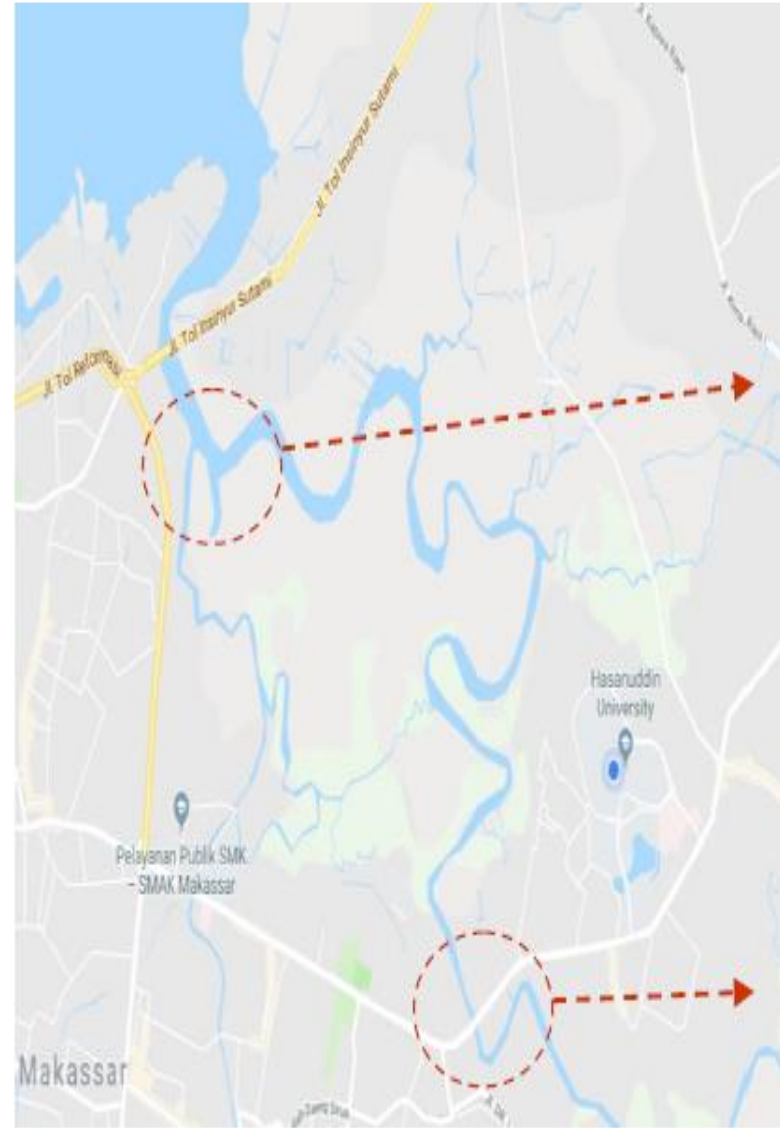

Sample of sediment, water, and plant parts of Nipah (Nypa fruticans) were acquired in July 2018.

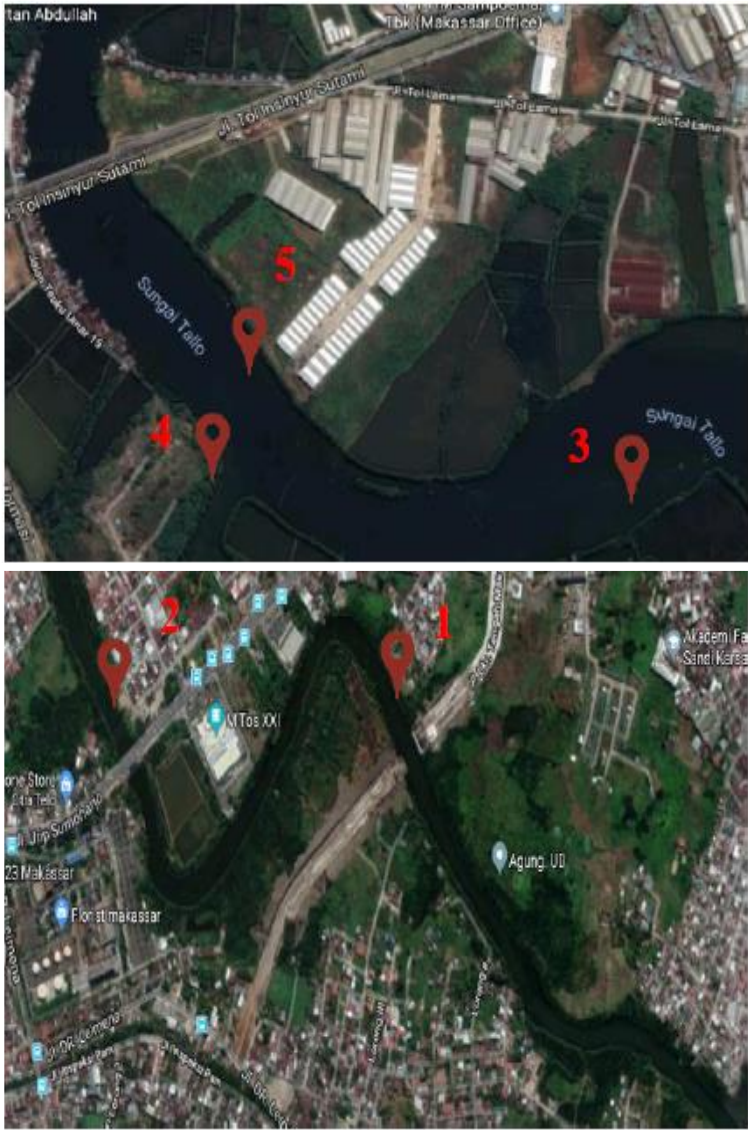

Figure 1. Map of Sampling Location

\section{MATERIAL AND METHODS}

\section{Tools}

The tools used in this research are GPS, eckman grab, water sampler, sample bag, ice box, cutting tool, oven SPN 150 SFD, Ohaus AP balance sheet 110, hot plate, ICP EOS Shimadzu 9000, porcelain cup, measuring flask, cup, funnel, and volume pipette.

\section{Materials}

The materials used in this study are water from rivers, sediments, roots, midribs, and leaves Nypa fruticans obtained from around the river Tallo, aquabidest, $\mathrm{HNO}_{3}$ (Merck), $\mathrm{H}_{2} \mathrm{O}_{2}$ (Merck), aquaregia, standard-element 50 ppm (Merck), $\mathrm{Na}_{2} \mathrm{CO}_{3}$ (Merck), $\mathrm{NaHCO}_{3}$ (Merck), and Whatman filter paper No. 42. 


\section{Procedures}

\section{Sample Preparation}

Samples of river water taken in the field and moved into polyethylene bottles, then added to $5 \mathrm{~mL}$ of concentrated $\mathrm{HNO}_{3}$, then stored in the icebox. River water samples were destructed by $5 \mathrm{~mL}$ of concentrated $\mathrm{HNO}_{3}$ then were evaporated to $10 \mathrm{~mL}$ on hot plate, then samples were filtered into $50 \mathrm{~mL}$ measuring flask with aquabidest $\mathrm{pH} 2$. Samples were homogenized then analyzed by ICP.

Samples of sediments that have been taken in the field then dried at 105 ${ }^{\circ} \mathrm{C}$ in the oven. Sediment that has been dried, destructed by weighing $2.5 \mathrm{~g}$ $\mathrm{Na}_{2} \mathrm{CO}_{3}$ into a porcelain cup and then added $0.5 \mathrm{~g}$ sediments and added more $2.5 \mathrm{~g}$ of $\mathrm{NaHCO}_{3}$ to cover samples of sediment, and then the samples were inserted into the furnace and heated at $850{ }^{\circ} \mathrm{C}$ for \pm 3 hours. Aquaregia was added to dissolve the destructed samples, then the samples were filtered into $50 \mathrm{~mL}$ measuring flask and then diluted to the line on the flask with aquabidest $\mathrm{pH} 2$. Samples were homogenized then analyzed by ICP.

Each sample of root, stem and leaves washed with distilled water then dried at $80-85{ }^{\circ} \mathrm{C}$ in the oven. Sample of root, stem and leaves have dried then crushed with a mortar. Each of the fine samples carefully weighed $0.5 \mathrm{~g}$ into a $100 \mathrm{~mL}$ beaker and added $15 \mathrm{~mL}$ of $\mathrm{HNO}_{3} 6 \mathrm{M}$ and $5 \mathrm{~mL}$ of $\mathrm{H}_{2} \mathrm{O}_{2}(\mathrm{p})$, then samples were heated at $60-80{ }^{\circ} \mathrm{C}$ until the volume becomes $\pm 1 \mathrm{~mL}$, then filtered into $50 \mathrm{~mL}$ measuring flask and diluted with aquabidest $\mathrm{pH}$ 2. Samples were homogenized then analyzed by ICP.

Standard solutions were prepared from multielement $50 \mathrm{ppm}$ into a series of solutions of the standard raw $\mathrm{Mn}$ and $\mathrm{Fe}$ using akuabidest $\mathrm{pH} 2$ with a series of 0.01 ppm; 0.05 ppm; 0.1 ppm; 1 ppm; 3 ppm; 5 ppm and 10 ppm.

\section{Determination of the Metal} Concentration

Concentrations of the metals obtained from the results of the analysis using ICP is calculated using the following equation:

$$
C=\frac{a x V \times f p}{g}
$$

Where:

$$
\begin{aligned}
\mathrm{C}= & \text { actual concentration } \\
\mathrm{a}= & \text { concentration from the results of } \\
& \text { ICP analysis } \\
\mathrm{V}= & \text { sample volume } \\
\mathrm{fp}= & \text { dilution factor } \\
\mathrm{g}= & \text { sample mass }
\end{aligned}
$$

\section{The Determination of Mechanism of The Absorption of Heavy Metals}

Concentration of the sample analysis as the data was processed by the formula of determining the value of the Translocation Factors (TF) and Bioconcentration Factors (BCF). Determination of heavy metal accumulation mechanism has been formulated by Ghosh and Singh (2005) as follows:

$$
\mathrm{TF}=\frac{[M] \text { in leaf }(\mathrm{mg} / \mathrm{kg})}{[M] \text { in root }(\mathrm{mg} / \mathrm{kg})} \times 100 \%
$$




$$
\mathrm{BCF}=\frac{[M] \text { average in plants tissue }(\mathrm{mg} / \mathrm{kg})}{[M] \text { contained in sediments }(\mathrm{mg} / \mathrm{kg})}
$$

$\mathrm{BCF}$ and $\mathrm{TF}$ values are used to determine the mechanism of the absorption of metals by plants. According to the Liong, et al., (2010), it is phytostabilization mechanism if the value of the $\mathrm{BCF}>1$ and $\mathrm{TF}<1$, whereas the mechanism is phytoextraction if the $\mathrm{BCF}$ $<1$ and $\mathrm{TF}>1$.

\section{RESULTS AND DISCUSSION}

The Concentration Of Heavy Metals In River Water

\section{Manganese}

River area is often polluted by heavy metals. Mn is one of heavy metals which contained in the wastewater from industrial areas that are usually not treated well and development activity that disposes of domestic waste into the river can diminish the water quality of the river (Judo, 2006). The results of the analysis of the $\mathrm{Mn}$ in the river water in the river Tallo is shown in table 1.

Table 1. Mn Concentration in water of Tallo River

\begin{tabular}{cc}
\hline Location & Concentration $(\mathbf{m g} / \mathbf{L})$ \\
\hline Station 1 & 167,05 \\
\hline Station 2 & 140,65 \\
\hline Station 3 & 135,85 \\
\hline Station 4 & 160,05 \\
\hline Station 5 & 161,55 \\
\hline
\end{tabular}

The results of the analysis showed concentrations of $\mathrm{Mn}$ in river water at all stations. Station 1 has the highest concentration of Mn, it was caused by the presence of zinc factory and PLTU, both these companies use $\mathrm{Mn}$ compound in their industrial activity, in addition there is road construction activities as well. Likewise with station 4 and 5 that are close to residential communities and Makassar Industrial Area. The magnitude of the concentration of $\mathrm{Mn}$ in the river water has passed through the limits of tolerance metal $\mathrm{Mn}$ in river water based on Surface Water Regulation of EU Directive Regulation by the Environmental Protection Agency which is $1 \mathrm{mg} / \mathrm{L}$.

\section{Ferrum (Iron)}

Source river water pollution can come from a variety of types of waste such as industrial waste, domestic waste, as well as other activities such as agriculture, fishing, and tourism. The level of pollution of river became increasingly high with increasing amounts of pollution load entering the waste stream and also due to the decreasing river flow discharge (Judo, 2006). The results of the analysis of Fe in the river water in the Tallo River is shown in table 2 .

Table 2. Fe Concentration in water of Tallo River

\begin{tabular}{cc}
\hline Location & Concentration $(\mathbf{m g} / \mathbf{L})$ \\
\hline Station 1 & 39,60 \\
\hline Station 2 & 16,15 \\
\hline Station 3 & 15,85 \\
\hline Station 4 & 41,60 \\
\hline Station 5 & 41,80 \\
\hline
\end{tabular}


Data in table 2 shows the highest concentration of $\mathrm{Fe}$ is at station 5 which is the point of confluence of the Pampang River and Tallo River. Station 1 is located near PLTU and zinc factory, while the Station 4 is situated in Pampang River that is contaminated from development activity. The magnitude of $\mathrm{Fe}$ concentration in river water has passed through the metal tolerance limit of Fe in river water based on Surface Water Regulation of EU Directive Regulation by the Environmental Protection Agency which is $2 \mathrm{mg} / \mathrm{L}$.

\section{The concentration of heavy metals in} Sediment

\section{Manganese}

Manganese liquid waste which precipitates to form sediments derived from industrial which uses $\mathrm{Mn}$ compounds for processing waste water and using $\mathrm{Mn}$ in matchsticks, batteries, and other community activities that can increase the concentration of $\mathrm{Mn}$ in sediments (anonymous, 2003). The results of the Mn analysis of the sediment in Tallo River is shown in table 3.

Table 3. Mn Concentration in sediment

\begin{tabular}{cc}
\hline Location & $\begin{array}{c}\text { Concentration (mg/kg, } \\
\text { dried weight) }\end{array}$ \\
\hline Station 1 & 13,89 \\
\hline Station 2 & 225,56 \\
\hline Station 3 & 906,74 \\
\hline Station 4 & $1.292,72$ \\
\hline Station 5 & $1.626,58$ \\
\hline
\end{tabular}

The results of the analysis showed that the concentration of $\mathrm{Mn}$ in all stations quite diverse with the biggest concentrations was found on station 5. The concentration of $\mathrm{Mn}$ is high on station 5 because station 5 is located right in the confluence of the Pampang River and Tallo River, so that pollution containing $\mathrm{Mn}$ along the Pampang River allegedly was washed away by currents and participate accumulated around Station 5. In addition, the location of the station 5 is near the industrial and community settlement activity that triggers the high concentration of $\mathrm{Mn}$. At station 1, the concentration of $\mathrm{Mn}$ was pretty low due on station 1 has $\mathrm{pH} 4$ in the water, this makes metal Mn tend to be soluble in water compared to settles as sediment. The weather during sampling was drought so that the flow of river water heading towards the coast of Tallo River be one of the factors of how low concentration of $\mathrm{Mn}$ in station 1 was.

The magnitude of the concentration of $\mathrm{Mn}$ in sediments have been over the limit of tolerance metal $\mathrm{Mn}$ in sediments based on Guidelines for Classifying Sediments of the Great Lakes Harbors for Heavily Polluted by the U.S. Environmental Protection Agency i.e. $1,100 \mathrm{mg} / \mathrm{kg}$ dry weight.

\section{Ferrum (Iron)}

Iron waste contamination in sediments were derived from waste industrial and community activities that can be a major factor of increased $\mathrm{Fe}$ concentration in sediments (Dima et al., 2006). The results of the analysis of $\mathrm{Fe}$ in 
the sediments on the river Tallo were indicated on table 4 .

Table 4. Fe Concentration in sediment Location Concentration (mg/kg, dried weight)

\begin{tabular}{cc}
\hline Station 1 & 356,55 \\
\hline Station 2 & 432,70 \\
\hline Station 3 & $2.650,46$ \\
\hline Station 4 & $3.098,99$ \\
\hline Station 5 & $2.470,17$ \\
\hline
\end{tabular}

The data in table 4 shows the concentrations of $\mathrm{Fe}$ in the sediments is quite large at stations 3, 4 and 5. The high concentration of $\mathrm{Fe}$ on the sediment was caused by the large number of industrial activity in the vicinity of airports, as well as river flow accumulative nature with a long period of time and continuously. The greatest concentration of $\mathrm{Fe}$ was on station 4 , this is due to the location of the station 4 is located on a tributary of Pampang River which is very close to residential communities, moreover very much junk was found on station 4 while doing the sampling. While on station 1 shows the lowest concentration of $\mathrm{Fe}$ among the five stations because station 1 is located quite far from the residential community and industrial activity. The magnitude of $\mathrm{Fe}$ concentration in the sediment of the river indicates the level of Tallo impurities that is already very high. Concentrations of $\mathrm{Fe}$ in sediments has not exceeded the tolerance specified by the Guidelines for Classifying Sediments of the Great Lakes Harbors for Heavily Polluted by U.S Environmental
Protection Agency (EPA US) which is $20.000 \mathrm{mg} / \mathrm{kg}$ dry weight

\section{Metal Concentrations In Plant Parts}

\section{Manganese}

Concentration of $\mathrm{Mn}$ in the plants give almost the same accumulation pattern in each station. At stations 1, 2 and 3 the concentration of $\mathrm{Mn}$ in the leaves is still very low so it is was not detected by the ICP. While on station 4 and 5, the distribution of Mn has reached the leaves which is marked by a considerable concentration of $\mathrm{Mn}$ in the leaves. The results of the analysis of the $\mathrm{Mn}$ in the Palm plant parts is shown in table 5 .

Table 5. Mn Concentration in Nipah (Nypa fruticans) plant parts

\begin{tabular}{|c|c|c|}
\hline Sample & Location & $\begin{array}{c}\text { Concentration } \\
(\mathrm{mg} / \mathrm{kg})\end{array}$ \\
\hline \multirow[t]{3}{*}{ Station 1} & Root & $2.434,20$ \\
\hline & Midrib & $1.598,61$ \\
\hline & Leaf & - \\
\hline \multicolumn{2}{|c|}{ Total } & $4.032,81$ \\
\hline \multirow[t]{3}{*}{ Station 2} & Root & $2.663,28$ \\
\hline & Midrib & $1.793,90$ \\
\hline & Leaf & - \\
\hline \multicolumn{2}{|c|}{ Total } & $4.457,18$ \\
\hline \multirow[t]{3}{*}{ Station 3} & Root & $2.670,19$ \\
\hline & Midrib & $1.933,40$ \\
\hline & Leaf & - \\
\hline \multicolumn{2}{|c|}{ Total } & $4.603,59$ \\
\hline \multirow[t]{3}{*}{ Station 4} & Root & $2.997,60$ \\
\hline & Midrib & $2.002,79$ \\
\hline & Leaf & 677,55 \\
\hline \multicolumn{2}{|c|}{ Total } & $5.677,94$ \\
\hline \multirow[t]{3}{*}{ Station 5} & Root & $3.250,54$ \\
\hline & Midrib & $2.281,77$ \\
\hline & Leaf & $1.116,60$ \\
\hline & tal & 6.64 \\
\hline
\end{tabular}


The metal that is absorbed by plants converted into substances that are needed by the body of the plant itself. The process of changing the metals from hazardous substances into substances that are needed by the body to form a chelate is called phytochelatin. Mn that is bounded by phytochelatin will be translocated to the plant to reduce the toxicity of Mn which is accumulated on roots, in addition, translocation of $\mathrm{Mn}$ in plant parts also serves in the process of photosynthesis which is distributed fairly evenly every part of the plant (Buchanan et al., 2000).

\section{Ferrum (Iron)}

Iron analysis results in table 6 shows that concentration of $\mathrm{Fe}$ in the roots is more translocated to the stem, this is because $\mathrm{Fe}$ is an essential metal for plants which is used in the process of photosynthesis and respiration by plants. One of the factors that affect the absorption of Fe in Nypa fruticans plant parts is temperature. Sampling was done in dry season so the plant leaf falls to reduce evaporation, which resulted that the allocation of $\mathrm{Fe}$ are most numerous in the boughs. This shows that the $\mathrm{Fe}$ translocation in Nypa furticans is most high in the boughs.
Table 6. Fe Concentration in Nipah (Nypa fruticans) plant parts

\begin{tabular}{|c|c|c|}
\hline Sample & Location & $\begin{array}{c}\text { Concentration } \\
(\mathrm{mg} / \mathrm{kg})\end{array}$ \\
\hline \multirow[t]{3}{*}{ Station 1} & Root & $7.159,11$ \\
\hline & Midrib & $45.582,67$ \\
\hline & Leaf & 541,86 \\
\hline \multicolumn{2}{|c|}{ Total } & $53.283,64$ \\
\hline \multirow[t]{3}{*}{ Station 2} & Root & $7.686,18$ \\
\hline & Midrib & $46.935,42$ \\
\hline & Leaf & 305,55 \\
\hline \multicolumn{2}{|c|}{ Total } & $54.927,15$ \\
\hline \multirow[t]{3}{*}{ Station 3} & Root & $7.396,69$ \\
\hline & Midrib & $47.818,09$ \\
\hline & Leaf & $1.119,10$ \\
\hline \multicolumn{2}{|c|}{ Total } & $56.333,88$ \\
\hline \multirow[t]{3}{*}{ Station 4} & Root & $39.298,56$ \\
\hline & Midrib & $49.222,80$ \\
\hline & Leaf & $38.961,42$ \\
\hline \multicolumn{2}{|c|}{ Total } & $127.482,78$ \\
\hline \multirow[t]{4}{*}{ Station 5} & Root & $40.683,75$ \\
\hline & Midrib & $50.949,49$ \\
\hline & Leaf & $41.941,17$ \\
\hline & Total & $133.574,41$ \\
\hline
\end{tabular}

Based on the results of the $\mathrm{Fe}$ analysis which is shown in Table $6, \mathrm{Fe}$ accumulation is most on the stem, then the roots and leaves in a row, but the last one is a little different with 5 stations on the amount of $\mathrm{Fe}$ in the roots and leaves, where the leaves contain $\mathrm{Fe}$ more than roots, it is caused by the chosen Nypa fruticans plant is probably the old plants and a very little population numbers around station 5 make them slightly different from the others. Accumulated Fe has range between $600-50,000 \mathrm{mg} / \mathrm{kg}$ dry weight. This concentration is higher than the concentration of $\mathrm{Fe}$ in Avicennia germinans in Amazon River and the 
Orinoco River in Brazil with 789.29 $\mathrm{mg} / \mathrm{kg}$ dry weight on average (Marchand et al., 2006), even it is in contrast to the accumulation ability of Rhizophorara cemosa in Rivers State of Nigeria that ranges $60,79-1641,36 \mathrm{mg} / \mathrm{kg}$ dry weight (Erakhrumen, 2015).

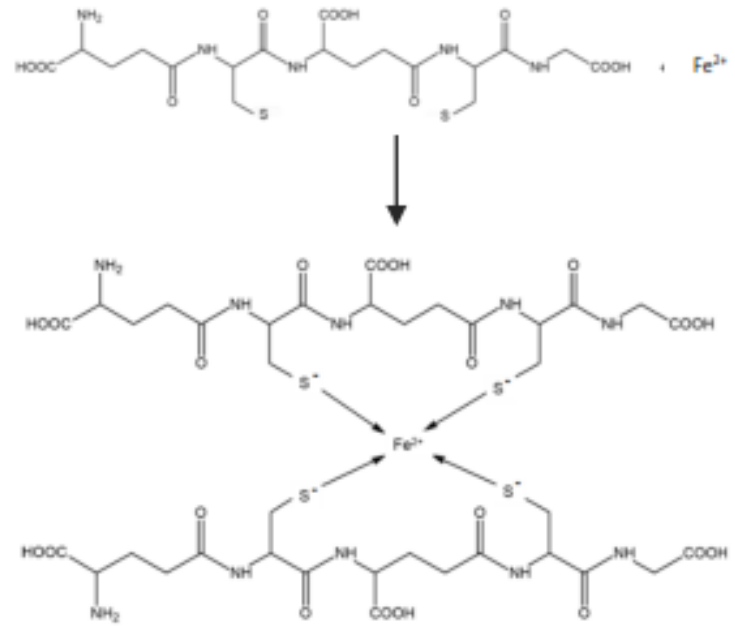

Figure 2. Phytochelatin reaction with $\mathrm{Fe}^{2+}$

Physiologically metal in high concentrations will foment response to plants. According to Hirata et al (2005), the plants respond to the presence of heavy metals in the environment in various ways, one of them with a phytochelatin protein synthesis which is a specific protein synthesized herbs to detoxify heavy metals by forming complex compounds. Phytochelatins have been found in various types of plants, fungi, even up to microalgae so that compound allegedly involved in translocations of $\mathrm{Fe}$ in Nipah plants (Nypa fruticans) is phytochelatin.

\section{Determination of Nipah Plant (Nypa fruticans) as Hyperaccumulator of Mn and $\mathrm{Fe}$}

Manganese in Nypa furticans plants analysis results data showed that Nypa furticans in Tallo River are not classified as hyperaccumulator plants of $\mathrm{Mn}$. A plant is called hyperaccumulator against $\mathrm{Mn}$ if the ability of the plant to accumulate $\mathrm{Mn}$ is greater than 10,000 $\mathrm{mg} / \mathrm{kg}$ dry weight. While the concentration of $\mathrm{Fe}$ that is accumulated in Nypa fruticans exceeded the minimum that is $10,000 \mathrm{mg} / \mathrm{kg}$ dry weight, so Nypa fruticans is said to be a hyperaccumulator against Fe (Pollard, 2009).

\section{BCF values and TF of Mn}

Data in table 7 shows the results of the calculation of the value of the $\mathrm{BCF}$ and TF in Nypa fruticans against Mn that all stations have the potential to be phytostabilization. When considered from the location of sampling, station 1, 2 and 3 is a palm plantation area, so the selected Nipah (Nypa fruticans) could be a plant that has previous harvest so the accumulation of $\mathrm{Mn}$ on the leaves is still low because the new Nipah grew a few months earlier, while station 4 and 5 is not a palm plantation area) so the selected nipah plants (Nypa fruticans) already accumulate $\mathrm{Mn}$ in the leaves so that sufficient concentrations of $\mathrm{Mn}$ were found high in leaves. Viewed from an overall $\mathrm{BCF}$ and $\mathrm{TF}$ value on table 7 , it can be ensured that Nypa fruticans has a phytostabilization potential. 
Table 7. BCF and TF values of Mn

\begin{tabular}{ccccccc}
\hline \multirow{2}{*}{ Location } & \multicolumn{9}{c}{ Metal Concentration (mg/kg, dried weight) } & \multirow{2}{*}{ BCF } & \multirow{2}{*}{ TF } \\
\cline { 2 - 6 } & Sediment & Root & Midrib & Leaf & & \\
\hline Station 1 & 13,89 & $2.434,20$ & $1.598,61$ & - & 145,1695 & \\
\hline Station 2 & 225,56 & $2.663,28$ & $1.793,90$ & - & 9,8803 & \\
\hline Station 3 & 906,74 & $2.670,19$ & $1.933,40$ & - & 2,5385 & \\
\hline Station 4 & $1.292,72$ & $2.997,60$ & $2.002,79$ & 677,55 & 1,4641 & 0,2260 \\
\hline Station 5 & $1.626,58$ & $3.250,54$ & $2.281,77$ & $1.116,60$ & 1,3626 & 0,3435 \\
\hline
\end{tabular}

\section{$\mathrm{BCF}$ and TF values of $\mathrm{Fe}$}

Data in table 8 shows that Nipah (Nypa fruticans), in terms of the value of $\mathrm{TF}$ and $\mathrm{BCF}$ is greater than 1, has the phytostabilization potensial. The selected Nypa fruticans as the object of research at station 1, 2, and 3 may be the young plants that were planted a few months back because the the sampling area is Nypa fruticans plantations area. But viewed from the overall value of the TF and BCF, it is certain that Nypa fruticans has the great phytostabilization potential when the accumulation of $\mathrm{Fe}$ has a minimum threshold of $\mathrm{Fe}$ in the sediment that is $20,000 \mathrm{mg} / \mathrm{kg}$.

Table 8. BCF and TF values of Fe

\begin{tabular}{ccccccc}
\hline \multirow{2}{*}{ Location } & \multicolumn{2}{c}{ Metal Concentration (mg/kg, dried weight) } & \multirow{2}{*}{ BCF } & \multirow{2}{*}{ TF } \\
\cline { 2 - 6 } & Sediment & Root & Midrib & Leaf & & \\
\hline Station 1 & 356,55 & $7.159,11$ & $45.582,67$ & 541,86 & 49,8141 & 0,0757 \\
\hline Station 2 & 432,70 & $7.686,18$ & $46.935,42$ & 305,55 & 42,3135 & 0,0398 \\
\hline Station 3 & $2.650,46$ & $7.396,69$ & $47.818,09$ & $1.119,10$ & 7,0848 & 0,0015 \\
\hline Station 4 & $3.098,99$ & $39.298,56$ & $49.222,80$ & $38.961,42$ & 41.1369 & 0,9914 \\
\hline Station 5 & $2.470,17$ & $40.683,75$ & $50.949,49$ & $41.941,17$ & 18,0250 & 1,0309 \\
\hline
\end{tabular}

\section{CONCLUSION}

Based on the results of the research that has been done, then it can be concluded that the greatest accumulated Mn translocation is in the roots, while the greatest accumulated $\mathrm{Fe}$ translocation is on the stems. The mechanism of absorption for $\mathrm{Mn}$ and $\mathrm{Fe}$ is phytostabilization. The total of $\mathrm{Mn}$ accumulation in Nypa fruticans represents that the plant naturally does not hyperaccumulate $\mathrm{Mn}$, but the total of $\mathrm{Fe}$ accumulation in Nypa fruticans suggests that this plant is naturally

hyperaccumulate Fe.

\section{REFERENCES}

Anonim, 2003, Health Effect Support Document for Manganese, United States Environmental Protection Agency, Washington DC.

Buchanan, B., Grusen, W., dan Jones, R., 2000, Biochemstry and Molecular Biology of Plants, American Society of Plant Physiologist, Maryland, Amerika Serikat. 
Dima, G., Popescu, I.V., Stihi, C., Oros C., Dinu S., Manea, L., dan Vlaicu, G., 2006, Fe, Mn And Zn Concentrations Determination From Ialomira River By Atomic Absorption Spectroscopy, Romania Journal Physics, 51(56):667-674.

Erakhrumen, A.A., 2015, Assesment of In-Situ Natural Dendroremediation Capability of Rhizophora racemosa in a Heavy MetalPolluted Mangrove Forest River State Nigeria, Journal Application Science Environment,19(1): 21-27.

Ghosh, M., dan Signh, S. P., 2005, Comparative Uptake and Phytoextraction Study of Soil Induced Chromium by Accumulator and High Biomass Weed Species, Applied Ecology and Environmental Research, 3(2): 6779.

Hirata, K., Tsuji, N., and Miyamoto, K., 2005,Biosynthetic Regulation of Phytochelatins, Heavy MetalBinding Peptides, Journal of Science and Bioengineering, 100(6): 593-599.

Juhaeti, T., Syarif, F., and Hidayati, N., 2004, Inventory of Potential Plants for Fitoremediation of Land and Degraded Water in Gold Mining, Biodiversity, 6 (1): 31-33.

Kariada, N.T.M., and Irsadi, A., 2014, Role of Mangroves as Biofilter of Water Pollution in Semarang Treadfish Pond Area, Human Journal and Environment, 21 (2): 188194.

Liong, S., Noor, A., Taba, P., and Abdullah A., 2010, Phytoaccumulation of Pb Study in Kankung Darat (Ipomoea reptans Poir), Department of Chemistry, Faculty of Mathematics and Natural
Sciences, Hasanuddin University, Makassar..

Pollard, A., J., 2009, Manganese Hyperaccumulation in Phytolacca americana L.from the Southeastern United States,Northeastern Naturalist, 16(5): 155-162.

Setiawan, H., 2014, Pollution of Heavy Metals in the Coastal Waters of Makassar City and their Mitigation Efforts, EBONI Technical Info, 11 (1): 1-13.

Widowati, W., Sastiono, H., and Jusuf, R., 2008, Effects of Toxic Metals on Pollution Prevention and Control, Andi, Yogyakarta.

Yudo, S., 2006, Pollution Conditions of Heavy Metal in DKI Jakarta River Waters, JAI, 2 (1): 1-15. 